\title{
Annexin A5
}

National Cancer Institute

\section{Source}

National Cancer Institute. Annexin A5. NCI Thesaurus. Code C21333.

Annexin A5 (320 aa, $~ 36 \mathrm{kDa}$ ) is encoded by the human ANXA5 gene. This protein plays a

role in the inhibition of blood coagulation and the transmembrane transport of calcium. 